\title{
Contemporary Nigerian Female Poets: Toyin Adewale and Unoma Azuah
}

\section{Sule Emmanuel Egya}

\section{(2) OpenEdition \\ 1 Journals}

Electronic version

URL: https://journals.openedition.org/ces/5458

DOI: $10.4000 /$ ces.5458

ISSN: 2534-6695

Publisher

SEPC (Société d'études des pays du Commonwealth)

\section{Printed version}

Date of publication: 1 April 2012

Number of pages: 7-17

ISSN: 2270-0633

\section{Electronic reference}

Sule Emmanuel Egya, "Contemporary Nigerian Female Poets: Toyin Adewale and Unoma Azuah", Commonwealth Essays and Studies [Online], 34.2 | 2012, Online since 19 April 2021, connection on 23 July 2021. URL: http://journals.openedition.org/ces/5458 ; DOI: https://doi.org/10.4000/ces.5458

\section{(c)}

Commonwealth Essays and Studies is licensed under a Licence Creative Commons Attribution - Pas d'Utilisation Commerciale - Pas de Modification 4.0 International. 


\section{Contemporary Nigerian Female Poets: Toyin Adewale and Unoma Azuah}

This essay is a reading of the poetry of Toyin Adewale and Unoma Azuah with a view to presenting contemporary feminist engagement in recent Nigerian poetry in English. The contention is that feminist engagement is increasingly moving towards an all-embracing commitment that considers the condition of women a larger part of the contemporary socio-political crisis in Nigeria. For these poets, the issue is not only about women seeking emancipation from patriarchal restrictions but the entire society striving for liberation from an establishment controlled by a powerful few.

In 1989, Obi Maduakor in his contribution to Nigerian Female Writers: A Critical Perspective opined that "[it] is in the area of poetry that the Nigerian female writers are still trailing languidly behind the menfolk on the literary scene" (75, my emphasis), his choice of adverb giving an unmistakable misogynist inflection to his appraisal. In 2008 Aderemi Raji-Oyelade published "Notes toward the Bibliography of Nigerian Women's Poetry (1985-2006)" which gathered "over fifty works that have been published in the past two decades by Nigerian women poets" (198). It is not the sheer increase of the female output within just two decades that begs attention here, but the intention of scholars such as Raji-Oyelade to deflect what they saw as a regime of male-dominated critical tradition that either turned a deaf ear to the voices of women or, as Maduakor did in his essay, condescended to include only a negligible proportion of them. In RajiOyelade's words, "the increasing publication of poetry by women authors has not been met with commensurate critical study of the emergent works" (199). Factual as the claim is, it seems overstated in the context of poetry produced since the 1980s, if one considers that within this period, usually referred to as the third generation of Nigerian writing (Adesanmi and Dunton 7-19), all genres of literature, not just women's poetry, suffered from a dearth of critical attention (Adesanmi 105-136).

The question for us is not the rationale adduced by the male critics' reluctance to pay attention to women's poetry, or even Raji-Oyelade's contention that the efforts of the female poets amount to "the progressive symbolism of the erasures of silence and self-effacement" (198). My concern is the recognition of the participation of female poets in the wider context of Nigerian poetry and their engagement with the leadership crisis in Nigeria in the last few decades. The contribution of women poets goes beyond what is narrowly perceived as the boundaries of feminism or womanism in Nigeria: selfrepresentation and the emancipation of women. The recent output of literary works by women in Nigeria, in all genres, calls for a re-mapping of what has hitherto been understood as feminism or womanism in the novels of Flora Nwapa, Buchi Emecheta, and Zaynab Alkali, to name but a few. These writers' feminism is mainly concerned with the subjugation of women at home and their struggles to extricate themselves from the socio-cultural restrictions that bind them to the whims and caprices of men. Consequently, critical engagements from diverse, mainly female, scholars have revolved around the position of woman as daughter, wife, and mother, in spite of stiwanism - the feminist 
theory elaborated by Molara Ogundipe-Leslie ${ }^{1}$ - or in spite of the far more expansive scope Chikwenye Okonjo Ogunyemi gives to womanism (Arndt, African Women's Literature 333). Aduke Adebayo, for instance, sees marriage as the ultimate root of women's problems: "Marriage [...] is one continuous hellish nightmare. Its inhibitions and restrictions stultify women's self-realisation and it is not until these women do away with their marriages that they are able to fulfil their individual destinies" (45). The point to be made here is that what one might call the first phase of feminism in Nigeria confines itself to the sphere of marriage, home, and the kitchen. As a result, the heroine emerges as the woman who can break out of matrimonial restrictions. In diverse postulations regarding the fate of women in their homes, one can discern the self-limiting subaltern discourse of this early phase of feminism, compounded, as it were, by the proliferation of sub-theories that claim to distinctively cater for the African woman: African feminism, womanism, Africana womanism, stiwanism, motherism, snail sense feminism, etc. It is not, however, in the scope of this essay to delve into the arguments informing these theoretical thoughts.

With the works of the third generation ${ }^{2}$ poets (dramatists and novelists), the persona or heroine is no longer satisfied with merely extricating herself from the cultural constraints that confine her, not only to her home but to the kitchen in her home. To be free from the kitchen, to marry a man of her own choice, to have lovely children, and to be a fulfilled mother are not enough. The heroine sets her gaze beyond this and realises, especially within the discourse of nationhood, that the nation in itself is a prison. The struggles of the emerging heroine are no longer for the emancipation of women only but of society as a whole. In addition to being a satisfied, socially-respected mother, she is a professional and a socio-political activist. This is the heroine of the new Nigerian female writers dramatised in Akachi Adimora-Ezeibgo's Children of the Eagle and Sefi Atta's Everything Good Will Come. In Atta's novel, Enitan's and Grace Ameh's activism puts them in the lead of the struggles to unseat military oppression. Even the outbursts of Mother of Prison speak volumes about a woman's capacity to engage in "serious" national issues beyond issues of matrimony. In this respect, Irene Danysh's claim that "the woman writer will more often deal with personal transformation and the male with public or societal transformation" (169) is no longer tenable today. Some recent feminist studies on new Nigerian writing have identified the dimensions that transcend the kitchen, concentrating on other struggles beyond those of matrimony (notably Orabueze; Bryce, "Half and Half Children" and "He Said, She Said"; Uko). I find Jane Bryce's "Half and Half Children': Third-Generation Women Writers and the New Nigerian Novel" exemplary of this paradigm shift. Bryce contends that "the feminine identity evident in earlier women's writing [...] has given way to a challenging reconfiguration of national realities" (49). She further asserts that "taken together, these novels [by a new generation of female writers in Nigeria] embody the effects of forty years of failed democratic rule and military dictatorship, corruption, state violence" (54). Her point is that the female voice has moved from that peripheral zone in which it

1. Stiwanism is an acronym for the "Social Transformation Including Women in Africa," a theory propounded by Ogundipe-Leslie to counter the opposition she met whenever she used the term "feminism" (Editor's note).

2. The first generation poets (notably Christopher Okigbo, Wole Soyinka, J. P. Clark-Bekederemo) produced poetry mingling private aspirations and public concerns, and was profoundly influenced by Euro-American modernism. The second generation poets (notably Niyi Osundare, Tanure Ojaide, Odia Ofeimun) adopted a Marxist aesthetics, and radically re-thought the poetic traditions and conventions their precursors had established. 
was only concerned with the fate of women to the centre in which the voice takes the fate of women as one of the issues to tackle. Thus, Bryce correctly points out that "[for] an alternative vision, and other 'possible types of relation' in the narrative of nationhood, we have to look to the new generation of women writing in Nigeria" ("He Said, She Said" 17).

The poetry written by women in Nigeria today mingles intimate female preoccupations with the larger concerns of the nation brutalised by successive military regimes. The poets consider the fate of women as a point at which action must be launched against the all-pervasive presence of military oppression and other indices of leadership failure in Nigeria. In this project, they see themselves as part of a larger design to deploy poetic discourse in the cultural struggles of the 1980s and 1990s. I shall now turn to the poetry of Toyin Adewale and Unoma Azuah to demonstrate that the female voice is an active component of the poetic discourse raised to counter the establishment.

Toyin Adewale distinguishes herself, among other things, as a literary stylist seeking a distinctive voice. ${ }^{3}$ From the beginning, her poetry has been anxious to assert its difference - in its imagistic mode, tonal modulation, and thematic thrust - from the tradition instituted by poets such as Odia Ofeimun, Niyi Osundare and Tanure Ojaide. Although her poetry is caught, inevitably, in the marketplace of influences in the relatively young Nigerian poetry, she succeeds in shaping a remarkably distinct voice. Adewale, at the beginning of her writing career, blazed new trails in Nigerian literature. She became a vital voice for the new generation by editing landmark anthologies such as Breaking the Silence (co-edited with Omowunmi Segun), Short Stories by 16 Nigerian Women, and 25 New Nigerian Poets in the introduction of which she points out the travails and triumphs of the new generation of poets. In many ways, Adewale emerged in the 1990s as one of the most important female poets of her generation, considering herself as an ambassador of that generation, especially in her travels and collaborations with writers within and outside Nigeria, which led, for instance, to the publication of the aforementioned anthologies.

Adewale's poetry prefers to be silently penetrative, a quality shared by some other female poets of her time such as Unoma Azuah. Her poetry does not name names. It is not reductively invective. It does not shout, although it occasionally employs startling metaphors that appear aggressive to patriarchy. Her sense of outrage is modulated in measured images, involved litotes, and characteristic brevity. Her nuanced vision remains, however, deeply feminist. There is even a sense in which the individualism and the abandonment found in her first collection Naked Testimonies seems to alienate itself from the communal sense evoked in the poetry of her generation. The poems gathered in Naked Testimonies have a tendency to be monologic. Occasionally addressing a "you," they are less descriptive of the national realities of the 1990s. But this, as further scrutiny will show, is a strategy whereby the singularity and individuality of the " $\mathrm{I}$ " subsumes the political edge of her generation's poetic vision. What is being driven at, here, is that the persona in each poem can be better understood when replaced in the social context of 1990s Nigeria, and all the clues contextualisation requires are present in the poem.

Naked Testimonies is as much about feminine love as it is about the throes of a society. The collection is first concerned with the emergence of the self, hence the emphasis it

3. Toyin Adewale-Gabriel studied at University of Ibadan. She has anchored literary pages for the newspapers The Guardian, The Post Express, and The Daily Times. She lives and works in Abuja, Nigeria. 
places upon love, the persona's discovery of her triumphal soul, and her desire to surpass the limitation of a male-centred world. Above all, the poems are about a nation, Nigeria, and the historicizing of the Nigerian condition. It is the characteristic angst running through Adewale's poetry that opens Naked Testimonies. The first poem "For T. J." begins with a moan soon turning into a wail, as the persona feels doubly imprisoned in love and in a harsh society:

And beyond this prison

I am a frozen ice cream

stubbornly awaiting you in the immense stadium

where love is sparkling like face cleanser

and fire,

passionate, consuming, melting the epiphanies of grief. (5-10)

What the persona calls "the epiphanies of grief" finds no appeasement in the opening poem, but constitutes one of the leitmotivs in the collection, underscoring the rage that informs many of its images. The other contrasting aspect of the collection is its mischievous humour, as in "Lemon Cream" where the triumphal lover, having found her/his lover, exclaims:

Soon thereafter, peace will step in to our door

to an embrace possessed of silence

and we will merge, I the lemon, you the cream.

We shall be christened Lemon Cream

I ripen, ready and reaching. (10-14)

Such cases of triumphing optimism coexist with moments of despondency surging from the deepest recesses of the soul. The persona's radiant energy, however, never fails to assert itself after moments of despair.

While each poem in Naked Testimonies has a certain, even if remote, connection with the historical events in Nigeria of the aforementioned period, some poems openly refer to a violent context, as in the questions hurled at the figure of oppression in "You Say Your Mouth Has No Blood?"

You say your mouth has no blood?

Three times I touched it

Three times I touched blood

Three times clotting and fresh

Who ate the

Head in the freezer

The liver in the cooler

Who stole in a heaving car?

See murdered dreams, your legacy,

How many pints of swamp your blood bank

$\mathrm{O}$ cohort of vultures? (12)

The head and the liver belong to a human victim murdered by this "cohort of vultures". The metaphor of blood deployed in this instance is all-pervasive in the poetry of this generation; and when it is thus used, it draws attention to the oppressed nation. ${ }^{4}$ Fear.

4. For an example of how blood is deployed as a metaphor or idiom in this form, see Olu Oguibe's $A$ Gathering 
The focus here is twofold as the poem questions the violent destruction of human beings through organised, systematised methods, but it also indicts the use of human parts by numerous African leaders for ritual purposes, as during the military dictatorship of Idi Amin Dada (1971-1979). The last question in the poem reveals, of course, that this is an on-going situation and that no one has done, or will do anything to stop it. The persona has the courage to touch the mouth of the bloodsucker in a gesture suggesting the propensity of African writers to question established situations, especially those that are harmful to humanity.

Adewale's second collection of poems, Die Aromaforscherin - originally published in Germany in a bilingual edition - is more openly concerned with national issues than the first. Here we do not encounter intensely personal situations, although the social space, as with most female writers in Nigeria, begins with intimate concerns. Perhaps the change of focus in this volume is best dramatized in "Safari," a poem "dripping with fire and gutters" (2). It is not that there are no other things to write about. One of the primary duties of a poet, as Adewale has come to imagine after Naked Testimonies, is to be sensitive, not only to the plight of women, but also to the fate of humanity in general. The poet declares, "I cannot lie that the blood in / my mouth is tomato sauce" (7-8), suggesting that she is aware of her privileged status as survivor and member of a well-fed elite, which problematizes her speaking in the name of the actual victims, those who do have real blood in their mouths and have remained silent.

In "A Prayer I," we encounter a persona apparently incapacitated as a result of the woe that has befallen her. Humbled to the nadir of hope in life, she seeks help from an authority that appears unwilling, or unable to raise her from her pitiable position in society. The first stanza of the poem shows that the persona has been struggling to survive by herself:

I have leaned on games

as if on sturdy pillars.

I have embraced a stone,

hearkening to a voice that lied in the

morning of dreams and fertile faith. (1-5)

Her struggle is obviously becoming futile. The same persona addresses the reader in the sequel "A Prayer II". Adewale's depiction of the female figure here amounts to what Chris J. C. Wasike calls the feminisation of nation. In his study of John Ruganda's drama, Wasike contends that Ruganda uses female characters and a feminist perspective to grapple with socio-political realities during the dictatorship of Idi Amin in Uganda, which ultimately leads to an engagement with the nation through feminism. His reading thus portrays how female "bodies can be read as canvasses that intersect between the semiotic and material dimensions of gender power and the imagination of the nation" (2). To locate this intersection in Adewale's poetry is to envisage the woman in "Prayer I" and "Prayer II" not only as exhibiting the qualities of the nation in which she lives, but as being herself the nation.

Adewale's poems feature two types of personae: the one who speaks, in fact acts, on behalf of the downtrodden woman; and the one who is herself the downtrodden woman and, as such, occupies the position of the victim. Because it is often impossible to tell these two personae apart, the poems constitute a vital site for interrogating the institution of maleness and the oppressive establishment against which most, if not all, 
the poets of Adewale's generation have had to elaborate a counter-discourse. Azuah is one such poet, and it is to her poetry that I shall now turn.

Unoma Azuah's poetry resonates with the tensions that erupted in Nigeria in the 1990s. The poet spent the same decade in Nigeria, experiencing for herself the confrontation with social, cultural and patriarchal authorities, and engaging with the political realities around her (Azuah 24-35). ${ }^{5}$ Sometimes the author's vibrant voice comes through her personae as a lone voice, demanding an individual space in a society that emphasises communality, drawing sympathetic attention to herself, but at the same time asserting her will to surpass the limitations of cultural institutions, even if no one comes to her rescue. In other instances, and perhaps more indirectly, her voice merges with the discourse of a generation of artists that struggled collectively against the institution of the military in Nigeria during the same period. Her style sometimes comes close to Toyin Adewale's perhaps less vociferous tone. Most of the time, however, Azuah sounds more determined, resolute, and single-minded than Adewale especially when it comes to the directness of her thematic approach. Whereas Adewale's poetry calls attention to itself through its aesthetic experimentation with metaphor and tone, Azuah's verse, although by no means devoid of aesthetic appeal, handles its thematic content in a blunter way. The difference here is essentially a matter of degree, suggesting that Azuah's writing emanates from a more uncomfortable zone of the imagination, where the individual is caught between internal and external pressures.

The personal agony of her personae is inextricably linked with the social anguish of Nigerian society - the result of the rampant militarisation of Nigeria in the last few decades. The word "night" in the collection Night Songs does not merely refer to the moment when the world comes to a rest and the female personae express their agony for being women, Nigerians, brutalised souls in a male-centred society. The night also refers to the darkness that befell the nation as it went through a time of misrule that devastated the poor, the civilians, the artists and the intellectuals. Like many of her contemporaries - for instance, Olu Oguibe, Ogaga Ifowodo and Uche Nduka - Azuah sought another space outside Nigeria and immigrated to the United States in search of daylight because the night in Nigeria, the songs of which she kept singing, would not end.

Night Songs thus contains elegiac images that depict the plunder of the land along with the violation of selfhood. The poem "Changes" is unmistakably about this. For all its brevity it captures the gamut of the nightlong catastrophes - ironically euphemised in the poem's title - that befell the land:

The dew of dawn cursed

the wrinkled face of the earth

In a dance of withering folds

leaves of the earth fry in fading colours

In strategic stances, grasses

sharpen their edges

Awaiting oppressive footsteps

Clumpy with dust

Clumpy with mud

Clumpy with heat

5. Unoma Azuah was born at Ogwashi-Ukwu in Delta State to a Tiv father and an Igbo mother. She studied at the University of Nsukka, where she edited the campus literary magazine The Muse. She now lives and teaches in the United States. 
In a dance of withering folds

All things in knitted pain remold. (56)

What Azuah calls the "dew of dawn" is the change that frequently comes with another oppressive regime being enthroned. The metaphor, of course, alludes to the coup d'état, the mode of power usurpation the military understood so well in the Nigeria of the 1980s and 1990s. The "dew of dawn" brings nothing other than a curse to "the wrinkled face of the earth," Azuah's figurative reference to what Ousmane Sembene so famously referred to as "God's bits of wood" in the title of his 1962 novel. The anthropomorphic metaphor calls attention to the pervasive effect of political oppression in Nigeria. The images of destruction, waste, and infertility echoed in the words "dust," "mud," and "heat" dramatise the damages that come with each "dew of dawn," namely with each martial song, each military incursion. The inevitable result is that "All things in knitted pain remold." The line bluntly ushers us into the police state in which the poet lived during the oppressive regimes of those decades. But the poem says nothing of the author's courage, her resilience in her opposition to the establishment, and the impact it had on her personal life. That is because Azuah gives us a picture of the condition of her country where, to use her engaging metaphor again, she does not wish to emerge as distinct from the "wrinkled face of the earth."

"Kogi State NYSC Camp '94" is one of the poems in which the persona faces the plague destroying her society. The tone is blunt and resolute:

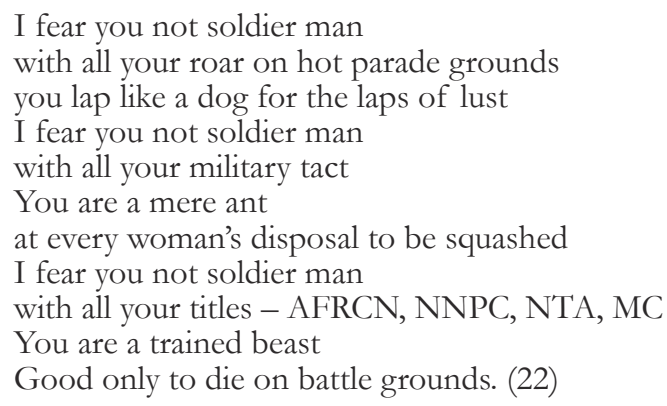

The paradox in this poem, reverberating through every image, is the paradox faced by Nigeria, and possibly by Africa: the persona hates the armed forces of the nation, to the extent of wishing the soldier dead, even on a battle ground. Moreover, the army, trained as it is to protect the integrity of the national territory, is viewed as "a trained beast." Of all things, the persona associates the soldier with vile, animal lusting. Instead of portraying the soldier as a national hero, as all soldiers would rather be regarded, the persona compares him to an "ant," one way of calling someone a coward. These paradoxes, obvious for anyone familiar with Nigerian history, are tied up with the local realities of military oppression. Successive military regimes instituted the superiority of the Nigerian army whose power did not come to rest on feats of heroism, but on despicable acts such as rapacity and rape, both literal and figurative. As a result, the military whether the officers or the rank and file - became social and societal villains. The poem challenges this institution using as a point of idiom the military instructors who trained Nigerian youths in National Youth Service Corps (NYSC) camps. The poem, however, transcends the immediate referential context of military training in Kogi State NYSC camp, and disparages the entire apparatus of military machinery in Nigeria. To this 
effect, the acronym AFRCN undoubtedly refers to the Armed Forces Ruling Council of Nigeria, the defunct mafia-like machine of military oppression in Nigeria. Likewise, NNPC stands for the Nigerian National Petroleum Corporation, the (up till now) national organ concerned with managing the oil resources of Nigeria, an organ that has served to enrich every succeeding military despot. NTA refers to the still extant Nigeria Television Authority, which has served as an effective propaganda outlet for the military oppressors in Nigeria. The acronyms refer the reader to external realities which beg to be deconstructed in the way I have done because they serve as codes that open up the extra-textual engagement of the poem with the political issues of Nigeria contemporary with the poem's composition. This passage highlights the intrepidity of a poetic project standing up to the police state in which Nigerians all had to live, that they all had to endure. No doubt, as Adeola James asserts, "[women] writers have been no less concerned than men to articulate and denounce the poverty, corruption and destructive practices that have impeded development in Africa" (4). But a courageous rebuff, even an indictment of the entire military and paramilitary exertions such as Azuah's, does not put an end to the crises tearing society apart. But if the soldiers got round to reading this kind of poem at all - its imagery and social semiotics making it accessible to everyone, soldiers included - they responded with tougher hostility, a situation that led poets such as Azuah herself to emigrate from Nigeria, primarily in order to survive.

It is therefore no wonder that the personae, along with their bravado should also express their helplessness and hopelessness in the face of a cruel social system and an established patriarchal subjugation. In "Thunderbolts," the persona speaks in the voice of a subdued soul:

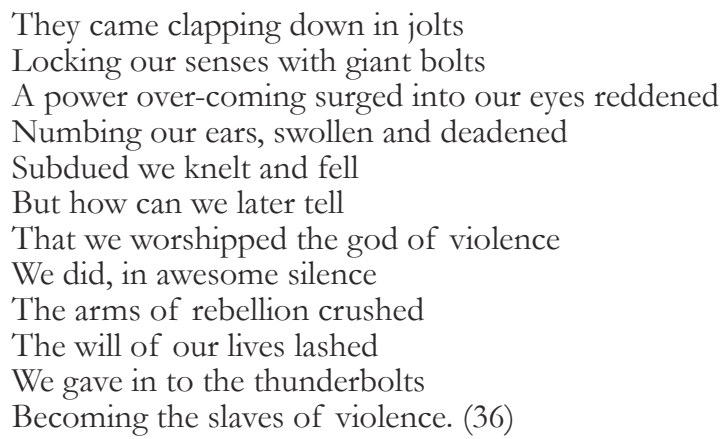

As in the poem previously discussed, despotism crushes all, the soul, the spirit of rebellion, even the art sustaining rebellion. The poem describes the enactment of pure power, here synonymous with the will for, and the monopoly of violence. It surpasses and crushes resistance, "the arms of rebellion," because it monopolises violence and deploys the machinery necessary for the effectuation of violence. The very instinct of every dictatorship, at least from what we can gather in retrospect about the Nigerian situation, is to guard itself, in the most aggressive manner, against the slightest form of opposition. When such conditions arise, for instance during the repressive dictatorship of Abacha in Nigeria (1993-1998), all kinds of artistic or cultural struggles are decimated. The image "Locking our senses with giant bolts" draws attention to the mechanism of destruction that every dictator institutes against artists, writers, cultural activists, and intellectuals. These are, of course, the perceived, sometimes feared, detractors of any 
despots. So, even before they reach the "arms of rebellion" to crush incipient forms of resistance, the dictator and his cohorts have to imprison, as it were, the exuberant thinking faculties of the select people gifted with the use of words and images to confront lies and illegal regimes. The persona includes herself/himself among those whose senses are locked with "giant bolts." This is natural because, given what we have seen in the previous poem, the persona has been operating as the detractor of military oppression, calling soldiers "ants." It is one duty that the persona owes society and would have continued assuming, but, as this poem makes explicit, the persona and her/ his fellow strugglers are hamstrung, contained and reduced to being "slaves of violence." It is therefore troubling that the persona should ask: "But how can we later tell / That we worshipped the god of violence". Herein lies the determination, the resolve to continue to speak in spite of the thunderbolts that now ruin their rebellious spirits. In other words, the poem's contention is that a poem should not yield to complicity with illegitimate forms of authority.

"Lekki Bitch" puns on the name of one of the most popular beaches in Lagos, indicating where the poem is located. It concerns itself with the plight of a single woman, better understood as a symbol of human indignity in a militarily oppressed Lagos. The poem gives us a picture of misery in three short stanzas:

Her belly thunders, a huge bulge

baring her bowels to the sky

Such style; the song she strokes

Her tongue licks the shores, begging

She roars in folds of blue

Teasing breezes

How she froths when we ignore her

Pregnant, she dances

Her belly, damp, deep and dark

Her fullness, a dressed awe

She is a long tongued beach

In depths, she lies in wait

Like death she waits and lures. (44)

This rendition of a wasted woman would ordinarily seem apolitical, especially as the poem does not bother to inform us of the cause of the woman's misery. But a contextualised reading of the poem reveals beyond the individual portrait an indictment of a nation that forsakes its own, condemning them to the precarious life on one of Lagos's beaches. Lekki Beach, in spite of its claim to touristic ventures, is a home as well as a commercial arena for pimps, underdogs, social outcasts, and criminals. The poem is replete with irony, forbidding the romantic vision of the female vagabond. Instead, she is viewed as a social threat: "Like death she waits and lures." Why should she be seen as a threat, when she is just one among the numerous people who survive on Lekki Beach, like Elvis in Chris Abani's novel GraceLand, eking out a living, playing music and performing in front of foreign tourists? Is the simile "Like death" not one of Azuah's ironic formulations to enhance the contradictions of a society fostering social ills and, at the same time, promoting sites such as Lekki Beach whose state function, among others, is to embrace tourism? It does seem that the persona in this poem, regardless of her "belly" thundering, of her "tongue" licking the shores, of her "roars," is more sinned against than sinning. She is one of those who became a beggar because of the 
hardships caused by the ruthless military regimes that misruled the country. The poem is pregnant with subversive innuendoes. Likewise, the woman carries her progeny, her belly a "huge bulge [...] damp, deep and dark." Of course, pregnancies ought to result in birth, but the poem gives us instead the eventual picture of death. This ambivalence is telling insofar as, beyond underscoring the contradiction in Lagos society, it brings to the fore the question of mortality both for the unborn child and for the restive mother, restive because she has to sing, possibly strike a wonky guitar, attempt (no matter how weakly) a few dance steps to beg for something to eat. There is no doubt that Azuah, in this poem as in other poems, intends to arouse our sympathy for this figure who has lived for so long on the beach that she merges with the coastal landscape and becomes an emanation of the sea.

Adewale's and Azuah's poetry give us a vivid portrayal of patriarchal restrictions, on the one hand, and of a repressive political system on the other. Their poems rage against such limitations and turbulent atmospheres, they seek freedom and accomplishment. As such, their writings deserve a place of their own in the artistic activism that arose to contest the military regimes of the 1990s. The poems have a feminist standpoint as their forte. But just as vivid is their presentation of the struggle and anguish of the nation, which proves that, beyond personal issues, "the dynamics of power in African societies is a major preoccupation expressed in African women's writing today" (Burango 67). In any case, very personal problems, such as the questions of gender and female sexuality, are not absent from their poetry. They, in fact, come first and often serve to allegorise the fate of the nation. ${ }^{6}$

Sule Emmanuel EGYA

Ibrabim Badamasi Babangida University

\section{Works Cited}

Abani, Chris. GraceLand. London: Picador, 2005.

ADEBAYO, Aduke. "Tearing the Veil of Invisibility: The Roles of West African Female Writers." Feminism and Black. Women's Creative Writing. Ed. Aduke Adebayo. Ibadan: AMD Publishers, 1996. 37-56.

Adeola, James. "Introduction." In Their Own Voices: African Women Writers Talk. Ed. Adeola James. Nairobi: Heinemann, 1990. 1-6.

Adesanmi, Pius. "Europhonism, Universities, and Other Stories: How Not to Speak for the Future of African Literatures." Palavers of African Literature: Essays in Honor of Bernth Lindfors. Ed. Toyin Falola and Barbara Harlow. Trenton, NJ \& Asmara: Africa World Press, 2002. 105-36.

- , and Chris Dunton. "Everything Good is Raining: Provisional Notes on the Nigerian Novel of the Third Generation." Research in African Literatures 39. 2 (2008): vii-xii.

Adewale, Toyin. Die Aromaforscherin. Stuttgart: Solitude Akademie, 1998.

—, ed. 25 New Nigerian Poets. Berkeley: Ishmael Reed, 2000.

—. Naked Testimonies. Lagos: Mace, 1995.

—, ed. Short Stories by 16 Nigerian Women. Berkeley: Ishmael Reed, 2005.

-, and Omowunmi Segun, eds. Breaking the Silence: An Anthology of Short Stories. Lagos: WRITA, 1996. Adimora-Ezeibgo, Akachi. Children of the Eagle. Lagos: Vista Books, 2002.

ARNDT, Susan. African Women's Literature, Orature and Intertextuality: Igbo Oral Narratives as Nigerian Women Writer's Model and Objects of Writing Back. Trans. by Isabel Cole. Bayreuth: Bayreuth Studies Series, 1998.

6. I would like to give credit to the African Humanities Program for the funding I received in support of the research that went into this article. 
—. "Paradigms of an Intertextual Dialogue: 'Race' and Gender in Nigerian Literature." Matatu: Journal of African Culture and Society 33 (2007): 199-221.

АттA, Sefi. Everything Good Will Come. Lagos: Farafina, 2005.

AzuaH, Unoma. Night Songs. Lagos: Oracle Books, 2001.

BRYCE, Jane. "'Half and Half Children': Third Generation Women Writers and the New Nigerian Novel." Research in African Literatures 39.2 (2008): 49-67.

—. "He Said, She Said: Gender and the Metanarrative of Nigerian Identity Construction." Ed. Aderemi Raji-Oyelade and Oyeniyi Okunoye. The Postcolonial Lamp: Essays in Honour of D. S. Izevbaye. Ibadan: Bookcraft, 2008. 317-43.

Burango, Monica. "Mothering Daughters and the Other Side of the Story in Amma Darko, Ama Ata Aidoo and Nozipo Maraire." Ed. Ernest N. Emenyonu. African Literature Today. 25. Ibadan: Heinemann, 2006. 67-81.

DanYsh, Irene. "Ama Ata Aidoo's Changes: The Woman's Voice in African Literature." Matatu: Journal for African Culture and Society 21-22 (2000): 164-72.

Maduakor, Obi. "Female Voices in Poetry: Catherine Acholonu and Omolara Ogundipe-Leslie as Poets." Ed. Henrietta C. Otokunefor and Obiageli C. Nwodo. Nigerian Female Writers: A Critical Perspective. Lagos: Malthouse Press, 1989. 75-91.

Oguibe, Olu. A Gathering Fear. Ibadan: Kraft Books, 1992.

Ogundipe-Leslie, Molara. Recreating Ourselves: African Women and Critical Transformations. Trenton, NJ: Africa World Press, 1994.

Orabueze, Florence. "The Prison of Nigerian Woman: Female Complicity in Sefi Atta's Everything Good Will Come." African Literature Today 27 (2010): 85-102.

Raji-Oyelade, Aderemi. "Notes toward the Bibliography of Nigerian Women's Poetry, 1985-2006." Research in African Literatures 39.1 (2008): 198-203.

Sembene, Ousmane. God's Bits of Wood. Trans. Francis Price. London: Heinemann, 1962.

Uko, Iniobong I. "Transcending the Margins: New Directions in Women's Writing." African Literature Today 25 (2006): 12-8.

Wasike, Chris J. C. "Feminization of the Ugandan Nation in John Ruganda's The Floods, The Burdens and Black Mamba." Postcolonial Text 5.3 (2009): 1-15. 